Polloy, Planning, and Research

WORKING PAPERS

Macrooconomlc Adjustment and Growth

Country Economics Department The World Bank

March 1989

WPS 162

\title{
Inflation in Argentina: Stop and Go Since the Austral Plan
}

\author{
Miguel A. Kiguel
}

Why did the Austral plan fail to curb inflation on a sustained basis? Sophistication in the design of a stabilization program is no substitute for addressing fundamental imbalances, contends the author - and price controls, improperly used, can make the problem worse. 


\section{WORKING PAPERS}

Macroeconomic Adjustment and Growth

The Austral plan, launched in 1985, was Argentina's most recent stabilization strategy for reducing high inflation. A heterodox program, it combined orthodox components - tioht fiscal policy and monetary restraint - with iess conventional wage and price controls.

The Austral plan failcd to bring inflation down on a sustained basis, but it provided useful lessons about the design of heterodox stabilization programs, the difficulties of sustaining this type of effort, and the consequences of failure.

Lesson 1, contends the author:

Sophistication is no substitute for addressing fundamental imbalances. Sustained curbing of inflation requires a long-term effort. Income policies can help bring inflation down quickly, but must be accompanied by sustained monetary and fiscal efforts. Tight money cannot be sustained in the presence of a large fiscal imbalance.

Fiscal reform and a restructuring of public sector enterprises were imperative, but were not undertaken.

\section{Lesson 2:}

To be effective, price controls must be used cautiously and only temporarily. They should gradually be removed when authorities see that the underlying inertial forces have been subdued.
The authorities did not think through how to liberalize prices - when, how, and under what condition to remove price controls - without bringing back inflation.

The chief advantage of controls is also their chief drawback. They can quickly reduce inflation, leading authorities to underestimate serious underlying imbalances. The repeated use of controls works against stabilization: anticipating freezes, firms set high prices. Anticipating re-imposition of controls, firms accelerate price increases. Controls should be removed gradually, when susplies generally are in excess, and tight fiscal and monetary policies should remain in place during "flexibilization." This was not done in Argentina.

In the Austral plan, the removal of controls coincided with a flexibilization in the management of the main anchors of the system. Gradual decontrol of private prices followed by a sequenced adjustment in wages, public sector prices, and the exchange rate would have had a better chance of success, the author argues.

The removal of controls left the economy with no nominal anchors - no nominal variable to anchor the rate of inflation. Given necessary adjustments in prices and the exchange rate, money should have played a more active role and the authorities should have pursued a policy of untying devaluations from past inflation.

This paper is a product of the Macroeconomic Adjustment and Growth Division, Country Economics Department. Copies are available free from the World Bank, 1818 H Street NW, Washington DC 20433. Please contact Raquel Luz, room N11059 , extension 61761 .

The PPR Working Paper Series disseminates the findings of work under way in the Bank's Policy, Planning, and Research Complex. An objective of the series is to get these findings out quickly, even if presentations are less than fully polishod. The findings, interpretations, and conclusions in these papers do not necessarily represent official policy of the Bank. 
TABLS OF COArEHTS

\section{$\underline{\text { Page }}$}

I. Introduction 1

II. Strategy and Implementation of the Austral Plan 4

$\begin{array}{lr}\text { A. Strategy } & 4 \\ \text { B. Implementation } & 6 \\ \text { C. Initial Results } & 16\end{array}$

III. The Stop and Go Cycle $\quad 18$

IV. Evaluation of the Recent Experience 27

References $\quad 36$

The views expressed in this paper are my own, and should not be attributed to the World Bank and its affiliated institutions. This paper was prepared as part of RPO é $674-24$, Stopping High Inflation. A very preliminary version of this paper was presented at the conference "Run-Away Inflation: Austerity at What Cost?: Argentina, Brazil and Israel," organized by the School of International and Public Affairs, Columbia University. I greatly benefited from Lengthy discussions with Ernesto Feldman and Nissan Livistan and from comments by Juan Carlos de Pablo, Bill Easterly, Federico Sturzenegger, Enrique Szewach, and Steve Webb. 


\section{Introduction}

Inflation is a chronic feature of the Argentine econony, one that has only turned worse over the years as inflation rates continuously crept up to higher and higher levels. Inflation has survivec the implementation of several serious and comprehensive stabilization programs, and the use of alternative stabilization strategles. The Austral plan was the most recent of these attempts.

There were three major stabilization effort prior to the Austral. The 1959 stabilization program under Frondizi was launched along strict orthodox lines. It was based on monetary and flscal discipline, and a sharp devaluation of the exchange rate. The program succeeded in bringing down inflation quickly (from 113 percent in 1959 to 14 perceat in 1961), but it: was not able to maintain it at the reduced levels for a significant pezad. An alternative appsoach was follow'd in 1967, under Rrieger Vasena. This program combined the adjustment in fundamentals (namely a reduction in the fiscal deficit) with an income policies package. It was also successful in the short run, and achieved price stability for almost three years, but inflation came back and even surpassed previous levels in the early seventies. After a short-11ved populist stabllization program during the Peronist guvernment, a third serious attempt was launched under Martinez de Ho2. That program started along orthodox lines (with some use of income policles), but 1te limited success in reducing inflation prompted a shift in otrategy with the exchange rate playing a central role as a stabilization Instrument. The future path of the exchange rate was preannounced in hopes that this would be an effective anchor to influence expectations and bring down inflation. The policy was effective in bringing down inflation 
(temporarily) at the cost of an overvaluation of the currency and severe external imbalances. The program collapsed in 19.91, and infl=tion moved up to an even higher level.

Despite the dissimilaritles in the design of these programs, most of them were able to strike transitory gains in the fight against inflation. The ultimate outcomes, however, were disappointingly similar. The programs were eventually abandoned as a result of a deterioration in the fiscal situation and in the balance of payments, and inflation returned invigorated reaching even higher levels.' As can be seen in figure 1 there has been a close relationship between deficits (messured as a percent of GDP) and inflation over the years, as well as a continuous inability to bring down the budget deficit on permanent basis. The fiscal cycles are an important feature of the Argentine economy; they have become a burden that any new stabilization program will have to deal with.

The Inflationary developments following the Martinez de Hoz era were complicated by the atmmtic and continuous deterioration in the internal and external economic conditions. The government budget deficit got out of control during the last years of the military government, exceeding by some estimates 20 percent of GDP, and remained basically unaffected during the first two years of the Alfonsin administration. On the external side, the situation deteriorated as a result of high interest rates, and a continuous fall in the terms of trade. The debt crisis made matters worse as the authorities were forced to finance these deficits aldost entirely through domestic sources. This is reflected by the large seigniorage levels (around

1 For a more detailed description of these episodes see Kiguel and Liviatan (1988) and de Pablo and Martinez (1988). 
8 percent of GDP) that were prevalent between 1982 and 1984.2

These massive, money financed budget deficits were the major source behind the relentless acceleration in inflation from 100 percent in 1981 to over 1800 percent during the second quarter of 1985. The situation was unsustainable and in the absence of drastic measures the economy was on its way to hyperinflation.

The Austral plan, launched in June 1985, provided a response to this cris18. It was a stabilization program whose maln objective was to pull down Inflation very quickly to manageable levels. Although the stated purpose was more ambitious, to restore price stability and eradicate inflation from the economy, the government never undertook the necessary measures to accomplish this goal. It was a heterodox program in the sense that it combined orthodox components, namely tight flscal policy and monetary restraint, with the less conventional instruments of price and wage controls. A new currency was Introduced, the Austral; the currency was devalued followed by an exchange rate freeze; and the effects of the unexpected reduction in inflation were neutralized through a novel mechanism based on the introduction of a conversion table for existing contracts (the "desagio").

The program was initially very successful in stoppling inflation. Inflation fell from 30 percent in June to 3.1 percent in August, when measured in terms of consumer prices, whlle the reductions were even more impressive in_terms of wholesale prices (See table 1). Unfortunately, as most stabilization efforts in Argentina, the Austral plan alsc failed. After

2 Selgniorage was measured as the changes in MI as a percentage of GDP. IIn Argentina MI, as opposed to the monetary base, is the appropriate monetary aggregate to measure aeigniorage because the central bank remunerates reserve requirements on time and other interest bearing deposits. 
one year of relative price stability, inflation rose again, reaching preAustral levels in 1988 .

The behavior of inflation following the fallure of the Austral plan has been different from previous eplsodes. Inflation did not excted prestabilization levels, as in all the other programs, but it became more volatile. As can be noticed from figure 2, the economy underwent conspicuous inflation-stabilization cycles (In October 87 and August 88 ) which cannot be directly linked to fiscal problems. In addition, the country was on the verge of hyperinflation in two occasions during this period (see figure 2) although the deficit and seignlorage did not return to pre-Austral levels.

This paper examines the behavior of inflation and other relevant macroeconomic variables since the beginning of the Austral Plan. It provides a more comprehensive evaluation of the program than in the existing 1iterature since it analyzes, within a unified framework, the various phases of the Plan. In this respect, it provides a boader perspective of the program and its evolution. Section II discusses the strategy of the original program and raises policy and analytical losues regarding its implementation. Section III traces the evolution of the program with particular emphasis on the inflation-8tabilization cycles and the inflationary outbursts. Section IV concludes with a discussion of some of the policy lessons from the Argentine experience regarding the implementation of the so called heterodox shocks.

II. Strategy and Implementation of the Austral Plan

\section{A. Strategy}


The Austral plan was a heterodox program which combined orthodox elements, such as flscal discipline and monetary restraint, with price ani wage controls. The basic strategy, discussed in more detail in de Pablo (1987), Canavese and DI Tella (1988), Frenkel and Fanel11 (1987), Heyman (1987), and Machinea and Fanel11 (1988 among others, attempted to provide a comprehensive response to the iarge exis:Ing imbalances in public finances and to thi inertial elements of the inflationary process. Orthodox measures alone are not sufficient to bring about a rapid disinflation process in chronic high inflation countries, such as Argentina, where inertial forces are at work. Inflation inertia can result from staggered nominal contracts, backward indexation of wages, or from lack of credibility about the sustainability of government disinfletion policies. The wage and price freeze was seen as the appropriate instrument to deal with this problem. The short run success of the program depended heavily on the ability to find rapid ways of reducing the large budget deficit and to engineer an effective strategy for dealing with the behavior of nominal variables. Its long run success required a permanent reduction in the budget deficit to a level consistent with the target of low inflation and the choice of a nominal anchor to make this objective feasible.

There seems to be wide agreement among analysts about the soundness of the Initial strategy, and on its great effectiveness for bringing down inflation quickly without large costs. Indeed, the initial policy measures as well as the overall results during this otage share many common elements 
with the more successful Israell stablization program of July $1985 .{ }^{3}$ There is jess consensus on the reasons that led to the resurgence of inflation during 1986; most analg8ts (e.8. Broda (1987), Rodriguez (1988)) blame it on the reappearance of Important fiscal Imbalances, while others think that it was caused by problems in managing nominal varlables, particularly wages, in a closed economy with imperfect competition (Frenkel and Fane111 (1987), Canavesa and DI Tella (1988)).

In the remainder of this section we will analyze these issues in perspective. We w11 briefly discuss the main components of the stabilization program, address potential weaknesses in the original design, and the initial results.

B. Implementation

The analysis will focus on four aspects: fiscal policy, management of prices, wages and the exchange rates, monetary policy, and monetary reform and "desagio".

a) Fiscal Policy

At the beginning of the program the authorities accomplished a significant adjustment in the fiscal accounts. There was a drastic reduction In the total budget deficit from 11.9 percent of GDP in the first two quarters of 1985 , to 1.8 percent in the third quarter (Table 2). ${ }^{4}$ A closer

3 For a detalled comparison of the two programs see Blejer and Liviatan (1987). Thet paper also discusees the 8 imilar behavior of macroeconomic varlables during the early stages of the programs.

4 Due to lack of accurate statistics on public sector expenditures, there 18 no consensus among observers about the exact magnitude of the size of the initial flecal imbalance. Neverthelese, all the available sources indicate that there was a oignificant reduction in the budget deficit, which was cut by approximately two thirds from the levels prevalling at the beginning of 1985 . 
analye1s, however, Indicates that most of this reduction was of a transitory nature and was likely to evaporate very quickly if inflation resurfaced. Government expenditure was basically unaffected by the program, although some adjustments had been done in the months preceding the plan. Reductions in real wages in the public sector and in public investment were done prior to the Austral plan, particularly during the second half of 1984 and the first months of 1985 .

Changes in tax revenues were the mafor force behind the improvement in the flocal accounts. The four main elements were an increase in trade taxes, higher public sector prices, the introduction of a forced savings scheme (whlch was essentlally a disguised tax), and improvements in tax collections resulting from the reduction in inilation. The first tax was the only one that could be expected to Increase revenues on permanent basis, although it was also the most detrimental for an efficient allocation of resources, since it Introduced an additional ant1-export blas at a time when the country was facing very serious problems on 1 ts external sector.

The realignment of public sector prices was largely attained prior to the program. This adjustment was reinforced on June 14 th when the authoritles increased them by 23.6 percent. As a result of these measures, relative public sector prices reached at that time their highest real value In the 1980s (see table 1). Thls favorable situation was not sustainable because public sector prices were part of the nominal anchors the suthorities were using to control the general price level. If Inflation were to continue, as it in fact did, the Inftial cushion in ralative prices would be lost weakening the budgetary position of the public sector enterprises. The forced savings scheme, was designed as ance and for all 
compulsory loan from individuslo and corporations to the govermment. In principle, this was not a tax, since the government had to repay that loan. Nevertheless, at that time, It was considered as genuine income for the purpose of calculating the budget deficit. In practice, It did work as a tax, because the government ended up borrowing at very low nominal interest rate which became negative with the increases in inflation in later years. The final element contributing to the increase in tax revenues was a gain in efficiency in tax collection which, paradoxically, resulted fron the reduction in inflation. Because most taxes are pald with a lag, an inc-easo In the rate of inflation erodes the real value of government revenues ..., 18 the well known Olivera-Tanzi effect). A drastic reduction in the rate of inflation works in reverse, resulting in an increase in the real value of tax revenues. Thus, the initial success of the Austral plan on the inflation side provided an important support for the consolidation of the fiscal oituation.

b) Prices, Wages and Exchange Rate Policies

The management of nominal variables was a central part of the program. A freeze of prices, wages and the exchange rate was introduced to deal with the inertial aspects of the inflationary process. The authorities realigned relative prices in order to avoid distortions during the freeze and to provide cushion in public sector prices and the real exchange rate. The duration of the freeze was not made explicit, but it was clear that this was a transitory measure and that efforts would be made to avold clear distortions in relative prices which $r \cdot 11$ have a detrimental impact on the allocation of resources.

In this respect the strategy was sensible and very similar to the more 
successful Ioraell program 5 . Nevertheless, the realignment-freeze approach has important Iimftations which are relevant for the evaluation of further developments and the interpretation of the later resurgence of inflation. Regardless of che effort made by the authorities they cannot realistically expect to hit the equilibrium vector of relative prices at the $t$ ime of the freeze. At best, they can attempt to avold clear Imbalances regarding the key government controlled prices (1.e. the exchange rate, and public sector prices and wag98). In this respect, past information, though useful, might not be very relevant. Equilibr: an relative prices change over time in response to new developments in the domestlc and international markets, and these changes are likely to be very drastic as the economy moves from high to low inflation. 6 A second difficulty arises because the government cannot realign every price in the economy. For the private sector the approach was to freeze prices according to the levels prevalling at a given date (June 13th in the case of the Austral). without any realignments. However, due to staggering of nominal contracts, the economy will have a "disequilibrium" structure of relative prices at any point in time. In Argentina, as well as in Israel, the extent of this problem was somewhat reduced because there was (1987).

5 The oimilarities are spelled out in more detail in Blejer and Liviatan

6 Two Important factors that influence prices are credit terms and the use of financial resources. Flrms that provide interest free commerclal credit to their customers have to include their financial costs in the price they charge. If there 18 a fall in inflation. firms should react by reducing nominal prices, the size of the reduction required will depend on the average length of these credits. A change in relative prices will occur when there are differences in the duration of these commercial credit lines provided by the various sectors. On the cost side, there are likely to be changes in the cost structure because as the economy moves to low inflation firms will increase the proportion of resources that they use in production and reduce those use to manage financial assets. 
a significant acceleration in inflation prior to the program which reduced the duration of nominal contracts hence Increasing the synchronization of price decisions. 7

The sireeze-realignment approach implicitly acknowledged that inflation would persist, though at a lower level. There was an initial overshooting of the exchange rate (which was devalued by 15 percent in addition of the large devaluations prior to the program) and public sector prices. This overadjustment was necessary to maintain the nominal values of these variables frozen in the presence of inflation. In the absence of these measures, the country would have faced a severe overvaluation of its currency as well as a deterloration in the fiscal accounts.

A different approach was adupted for wages, a third anchor to the system. Initial restraint in nominal wage increases resulted in a reduction in real wages, specially in tise public sector, ${ }^{8}$ which were important to support the fiscal effort and restraint demand. This, however, was the first variable to be flexibilized, and its role as anchor was probably weaker because private sector wages continued to grow during the freeze.

The final anchor were industrial prices ${ }^{9}$ which were subjected to direct controls. The freeze was effective at the wholesale level (rather than at the retail level), a feature that explains the dissimilarities in behavior

7 On this point see Pazos (1972).

8 The government raised nominal wages by 22.6 percent effective at the end of June. Th1s increase, however, was not enough to compensate for past inflation and was certainly smaller than the accumulated devaluation of recent months.

9 The freeze did not apply to goods with seasonal supplies (mainly meat, frults and vegetables) which were instead subject to fixed mark-ups over costs. 
between the CPI and the WPI during the early period.

In summary, the exchange rate and public sector prices were the main nominal anchors of the system, and they were supported by price and wage controls. The inftial realignment in relative prices, by providing a cushion to the two main anchors, increased the likelihood of success of the strategy.

c) Monetary Policy

The management of monetary policy and interest rates during the early stages of a stabilization program is a very delicate and difficult matter. The problem is specially difficult in those programs that are successful and achleve a rapid reduction in inflation. In many cases, however, interest rates have been slow to respond to the changes in inflation, leading to a drastlc increase in real interest rates. Two main reasons have been provided to explain this downsard rigidity in nominal interest rates f frst, it could result from the adoption of a very restrictive monetary policy by the central bank, and second it could be the effect of lack of credibility regarding the sustuinability of nominal variables.

The discussion can be clarifled with the help of the following set of equat Lons;

(1) $m=M / P$

(2) $1=5+x^{e}$

(3) $\mathrm{m}=L\left(x_{-}+x^{e}\right)$ L. $<0$.

Equation (1) 18 the definition of real money balances, where $M$ is the money supply and $P$ is the price level. Equation (2) states that the nominal Interest rate (1) 18 equal to the real interest rate (r) plus the expected 
rate of inflation $\left(\pi^{e}\right)$. Finally, equation (3) states the equilibrium conditions for the money market. This equation implies that there is an inverse relationship between real money holdings and the nominal interest rate. 10

As long as the money market remains in equilibrium low (high) real money balances will be assoclated with high (low) nominal interast rates. Empirically, however, It is difflcult to establish whether interest rates remain high because money 18 tight, or if instead real money balances stay at low levels because the equilibrium nominal interest rate continues to be high.

Those who consider that interest rates are high due to tight money (e.8. Dornbusch (1986)), argue that the "equilibrlum" real interest rate is determined in the real sector and assume that inflation expectations react quickly to new developments ( $x^{e}$ falls almost immediately after the implementation of the stabilization program). Tight monetary policy is responsible for the stickiness in nominal interest rates.

If prices were fully flexible in both directlons, an increase (a reduction) in real money balances could be effected through a reduction (an Increase) in the price level. In such a world, tight money would not be an obstacle for a fall in interest rates. This 18 not, however, a relevant case since in general there 18 downard inflexibility of prices. Nevertheless, there are in practice various mechanisms that could allow an increase in the narrow monetary aggregates. Agents could adjust their domestic portfollos

10 Under perfect capital mobility the domestic Interest rate will equal the foreign interest rate plus the expected rate of depreciation of the exchange. For the purposes of our discussion, however, the results can be derived elther by using equation (2) or the perfect capital mobility condition. 
and increase the stock of $M I$ relative to other financial assets. In addition, portfolios could be adjusted through international financlal flows. If interest rates are high, there would be capital inflows increasing the supply of domestic assets.

The alternative explanation assumes that there is stickiness in inflationary expectations (e.g. Sachs (1986)). Individuals do not believe that the program is going to last ( $\pi^{e}$ remains $h i g h$ ), hence, according to equation (2), Interest rates also remain high. Low real money balances are the result of high interest rates. To the extent that the rate of inflation (x) falls, $\pi<x^{e}$ and ex-post real interest rates w1l be high. However, according to this view, ex-ante real interest rates are not necessarily h1gh.

A mistake in the diagnosis of the causes for high interegt rates will be costly for the economy. If the government wrongly thinks that interest rates are high as a result of tight money and tries to deal with this problem by Increasing domestic credit, It will create an excess supply of money and In the end destablize the anti-inflation process. If on the other hand it errs by using tight money and hence allowing real interest rates to remain high it will decrease Investment, and possibly worsen the flscal accourts. Since an accurate diagnosis is in practice very difficult, the government has to choose which alternative 18 less risky given its own prlorities. - If 1 ts main goal is to succeed in bringing down inflation, then It is safer to err on the 8 ide of $\mathrm{h}$ igh real interest rates than on the 8 ide of excess demand pressures in the goods market. In countries such as Argentina a short period of high real interest rates is a price worth paying if that would could insure low inflation in the longer term. 
The avallable evidence indicates that the authorities followed a prudent approach at the outset of the program. There was a large increase in domestic credit (and in the money supply) prior to the program and during its first weeks, which contributed to the sharp reduction in monthly nominal interest rates from 30 to 6 percent (see table 1 ). The initial monetary expansion primarily accomodated the increase in money demand resulting from the reduction in the opportunity cost of holding money in a low inflation environment. Despite its $81 z e$, it did not create an excess supply of money as illustrated by the capital Inflows that entered the country during the first two weeks of the program (estimated in USs 300 million). 11 In fact, a policy of easy money would have led to capital outflows. The overall evidence indicates that the government followed a reasonable monetary policy during the very early stages of the program. However, as will be discussed later, monetary policy remained sound only for a very short span.

Money did not play a central role as a nominal anchor in the program. Even in the early stages, In spite of the high ex-post real interest rates, most analysts consider that monetary policy was primarily accommodating. 12 Although there were a few instances in which the authorities followed a policy of tight money, they were relatively short lived and were abandoned once it was apparent that the consequence was a long period of high real Interest rates.

d) Monetary keform and "Desag10"

Two Interrelated elements of the program were the monetary reform, and

11 After that time capital flows slowed down mainly because the government imposed additional restrictions on capital movements.

12 See for example Heyman (1987) and Frenkel and Fanel11 (1987). 
the desagio, an ingenious scale of conversion aimed at minimizing the transfers between borrowers and lenders that would result from an unanticipated sharp reduction in the rate of inflation.

The monetary reform consisted in the introduction of a new currency. the Austral. One Austral was equivalent to 1,000 units of the old currency (the peso). Monetary reforms of this type had been done twice before (in 1970 and 1983), and in both cases they only meant a change in numeraire and had no effects on inflation or expectations.

The monetary reform in the Austral differed in two ways. First, the new currency was introduced as part of a comprehensive stabilization package. Although the Austral was fiat money and was not backed by any real assets, its Introduction was accompanied by an announcement not to print any more money to finance the budget deficit. This promise, if fulfilled, was specially important since there was a wide (and well founded) perception at the time that central bank financing of the deficit was at the core of the inflationary process. Second, and more important, the new currency was necessary on legal grounds to make the desagio possible.13

A rapid and unanticipated reduction in inflation will, in general, redistribute income (and wealth) from debtors to creditors. At times when Inflation is high, nominal interest rates also tend to be high in order to malntaln a constant real interest rate. In high inflation economies, changes in nominal inferest rates are primarily determined by changes in the expected rate of inflation. When the Austral plan was launched, inflation and interest rates were close to 30 percent per month. These interest rates were

13 I am grateful to Enrique szewach for pointing out the legal difficulties for the implementing of the desagio in the absence of a new currency. 
based on the assumption that inflation would remain at those levels in the near future.

The sharp disinflation accomplished by the Austral plan was an unforseen event for lenders and borrowers. Nominal interest rates contracted prior to the plan would have resulted in extraordinary high ex-post real interest rates (close to 20 percent per month), To avoid these effects the government introduced a mechanism (the "desagio") that converted the value of financial agreements orlginating prior to June 14 with maturities after that date according to a predetermined rule. This was effected through the Introduction of a scale of conversion from Pesos into Australes for those financial obligations maturing after June 14. This mechanism was particularly important for the public sector (including the central bank) whicn was a net debtor. 14 It 18 conceivable that in the absence of the "desagio" the budget deficit could have been 1 or 2 percentage points higher than it actually was during the first months of the program.

C. Intelal Results

By and large this was a well designed program to combat inflation. It showed an appropriate balance between orthodox and heterodox measures that are necessary to stabllize quickly and without large social costs. The main potential problems for the success of the plan were on the fiscal side, where the adjustment, although significant, was largely based on short term measures and hence was extremely fragile, and on the viabilit.y of the exchange rate freeze glven the 1 imited access to forelgn borrowing as a

14 Most of the public sector domestic debt was in the form of deposits of commercial banks in the central bank and other rypes of "forced" lending through the banking system. A comprehensive study of these aspects will be done in future research. 
result of the debt crisis. Sustainability of the program required that the authorfties would introduce very quickly a mafor fiscal reform aimed at improving government revenues on a permanent basis, and that they could maintain inflation at low levels in order to avold overvaluation of the currency.

The initial results were very impressive, but similar to other programs based on economy-wide controls. Inflation fell from 348 percent per semester in the first half of the year to 20.2 percent in the second half. The adoption of price controls was very important for the sharp disinflation, although their exact role in the stabilization effort remains unclear. The government did not develop any enforcement mechanisms to check compliance with price regulations, so the reduction in inflation was mainly due to "voluntary" compliance by the private sector. In addition, the controls did not produce excess demands and hence shortages in most markets. The initial success was enhanced by an improvement during the third quarter in the current account of the balance of payments, and only a small reduction in the level of economic activity (see table 3 ).

Despite the aura of success some worrying signs started to develop in the fourth quarter. While Inflation remained at relatively low levels (at 2.5 percent per month), the current account turned into deficit and the economy moved very quickly into an expansionary cycle, mainly propelled by a consumption boom_(table 3 ). These events were troubling since an increase in demand can weaken the anti-inflation effort while the deterioration in the balance of payments was likely to reduce the abllity to maintain the fixed exchange rate, hence lessening the credibility of the program.

The evolution of nominal variables made it clear that inflation was 
golng to stay, though very likely at much lower levels. As can be noticed in table 1, money supply continued growing throughout the year. After the Initial large increase to satisfy the increase in the demand for money. MI and $M 4$ expanded respectively 64 and 50 percent between August and December of 1985. Although part of this expansion was certainly absorbed by increases in the demand for money, its size was incompatible with an objective of zero inflation and it undermined the credibility of the program. 15

In addition, the persistence of inflation, even at the much lower levels, and the wage increases granted by the private sector and public enterprises created problems for the sustainability of the freeze of the exchange rate and prices of public sector enterprises. The initial cushion was slowly being eroded and it was becoming increasingly apparent that there was a need to change the rules for the nominal anchors and to design a strategy to get out of the freeze.

\section{The Stop and Go Cycle}

The first adjustment was undertaken in April 1986 with the announcement of the "flexibilization" phase of the program. On April 4, there was a devaluation of the exchange rate, accompanied by the introduction of a crawling peg system, and increases in wages and prices of public sector

15 Two facts can be used to question the soundness of these increases in the money supply. First, in spite of its size, it did not produce any significant reductions in interest rates. Second, in the fourth quarter the balance of payments turned into deficit after being in surplus for the two prevlous quarters, thus suggesting that at those interest rates there was not an excess demand for money. 
enterprises.16 Despite the flexibilization in policies, the government continued to control prices in the private sector, although increases would be allowed in the future when justified as the result of higher costs.

This flexibilization was necessary in view of the persistence of inflation, and the inability to withstand an overvaluation of the domestic currency. It was prompted by the acceleration in inflation in March 1986 and by the continuous deterioration in the current account and the budgetary situation (see tables 2 and 3 ). The reduced access to forelgn financing, as a result of the debt crlols, imposed an additional limit to the sustainability of the exchange rate freeze.

a) Price Flexibilization and the Resurgence of Inflation

The introduction of the April package was perceived as an acceptance on the part of the authorities that full price stability was beyond their reach and that they were now aiming at keeping inflation within reasonable bounds. With this acceptance there was also an acceleration in infiacion, which reached 6.8 percent in July (table 1 ).

A more serious problem was the lack of a comprehensive strategy to maintain inflation within reasonable bounds. The flexibilization stage left the system without effective nominal anchors. The exchange rate and public sector prices (central anchors in the initial package) were going to be adjusted according to past inflation in order to avold further deterioration In their relaflve prices. In fact, nominal increases in these two varlables exceeded inflation between April and July. Nominal wages, the third anchor in the initial program were increasingly determined through negotiations

16 For a more detalled discussion of the measures see de Pablo (1987). 
between unions and Industrislists since monetary policy continued to be accomnodating there was no nominal varlable in the system that could provide an anchor for the price level.

In such a situation nominal shocks have a destabilizing effect on inflation. A one time increase in the price level will be quickly transmitted to wages and the exchange rate and will result in a permanent increase in the rate of inflation. 17

The main reason underlying the acceleration in inflation that occurred after flexibilization was and continues to be a controversial issue. Broadly speaking, there are three interpretations of this episode, one emphasizing problems in the behavior of nominal variables, a second stressing the imbalances in relative prices during the inftial freeze, and a third attaching a larger weight to the flocal and quasi-fiscal imbalances.

Frenkel and Fane111 (1987, p.103) and Kachinea and Fanel11 (1988 p.142) Iink the acceleration in inflation to cost-push factors, primarily increases in nominal wages. The evolution of hourly wages during this period is presented in table 1 . As can be noticed, hourly wages increased continuously during the first months of the Plan, whlle there was a sight acceleration in April. Real hourly wages, however, had been deterlorating since the beginning of the plan, and the fpril and May increases were not enough to restore their real value to pre-Austral levels. The other two major cost tactors, the exchange rate and public sector prices, were not drastically increased in this period (see table 1). Thus, the acceleration in inflation

17 Adams and Gross (1986) provide and excellent discussion of the difficultes of controlling inflation with exchange rate indexation and monetary accomodation. 
between April and June does not seem to have been driven by cost push factors.18 The story is somewhat different in July, where nominal increases probably had an important effect in the increases in inflation. 19 Indeed. real wages (as well as hourly wages) peaked in July and were later eroded by further increases in inflation.

Canavese and Di Tella (1988) on the other hand, consider that the resurgence of inflation during the flexibilization period was due to the imbalances In relative prices that were bullt at the time of the freeze. They argue that "Pressures steming from the inevitable need to realign prices troubled the Austral plan the most and made the unfreezing essential. But at the same time the end of the freeze had a troubling effect on Inflation, as it became apparent the following year." (p.159) If this argument is right, it implies that a period of high inflation will be followed by another period of low inflation. However, this argument fails to explain what determines the rate of inflation in the new equilibrium. More Important, it does not provide a rational for the acceleration in inflation that occurred after Apri1.20

18 The large increases in hourly wages in the consic.lction industry during April could convey the impression that cost push factors vere important in that sector. However, a more careful examination of the dato indicates that wages in this sector did not experlence almost any increase duing the first months of the Austral. Thus the April incresse basically restored relative wages.

19 The interpretation of this complicated by the fact that during this period some labor unions obtained significant wage increases. The problem is that it is difficult to assess the extent to which these increases merely "officialized" previous wage increases that were already reflected in the actual paid (as opposed to the contract) wages.

20 For a thorough evaluation of this argument see Rodriguez (1988). 
The third interpretation puts the emphasis on the continuous and excessive Increases in the money supply and the loosening of the budgetary situation (see tables 1 and 2 ) during the first quarter of 1986 . In addition, the large selgniorage levels (In excess of 3 percent of GDP) on a sustainable basis were inconsistent with the target of inflation in the low single digits. The April flexibilization thus took place in an expanding economy with high consumption and increasing budget imbalances. Under these circumstances, a resurgence of Inflation was all but inevitable.

The fiscal view can be used to explain why increases in inflation had to be expected. The existence of relatively large budget deficits and selgniorage level ranging between 3 and 4 percent of GDP put a floor on inflation rates. The sharp acceleration in inflation that took place during July and August, however, cannot be solely explain on flscal grounds.

A comprehensive explanation of inflation during this period requires a combination of the ideas outlined above. The large budget deficits and high selgniorage levels made inflation unavoldable. However, seigniorage levels of a percent of GDP can be financed with a monthly rate of inflation of 5 percent given that MI was approximately 52 of GDP. The acceleration of July appears to have been caused by additional factors. Although cost-push forces were probably important, they would have been less destabilizing if the system had had a nominal anchor.

\section{b) The first Spring Plan}

The July 1986 inflation rate brought the program to a critical point; the situation was getting out of control and urgent changes were needed to bring it back in course. A new team took control of the central bank at the end of August and immediately adopted a very tight stance regarding 
expansione in M (table 1).21 Money was in practice the only nominal anchor In this program. The first Spring plan did not introduce measures to deal with the fiscal imbalances (oince according to the authorities the fiscal situation was fundamentally sound) and instead placed its emphasis on the problems created by inertial forces; it established ceilings ( 3 percent) for monthly increases in prices in the private and public sectors as well as Iimits on wage increases.

The Spring plan had 1 imlted success in controlling inflation, which despite receding, remained at relatively high levels for the rest of the year. The underlying situation was not conducive for attaining price stability. Despite tight money and higher interest rates (the nominal Interest rate almost doubled in August), real wages, industrial production and consumption remined relatively $\mathrm{hlgh}$, although at somewhat lower levels, and the external situation continued to deteriorate. While there is disagreement among observers about the fiscal situation in the third quarter (table 2), there 18 no question that the fiscal and monetary accounts greatly deteriorated in the last quarter of 1986.22

The Initial anchors were by then abandoned, and money remained as the only nominal anchor. Despite the announcements of limiting the devaluations

21 The drastic chenge in monetary policy adopted at that $t$ ime was necessary to insure the consistency of the program. The discrepancles between the economic team (led by Sourrouille) and the central bank authorities (led by Concepcion) are well documonted in the Argentinean Press of the period. At the same time, the drastic change in monetary stance in August provides indirect evidence that the mismanagement of money oupply was considered, at least at some government levels, as one important force behind the resurgence of inflation.

22 For cyclical reasons the budget deficit is usually larger in the last quarter of the year. Nevertheless, the incrase in the deficit towards the end of 1986 cannot be fully explain by seasonal factors, for one thing, it was much larger than in the last quarter of 1985. 
and the increases in public sectors prices to 3 percent per month, they were in effect indexed, raising consistently by more than the officlal guideline. The package relied almost entirely on tight money, but the sustainability of this strategy was very difficult to the extent that there was an inconsistency between the growth rates of money and other nominal variables. c) Resurgence of Inflation and the Second Freeze

Inflation increased once more in January 1987 and there was an even larger increase in February. Th1s rise in inflation was particularly troublesome since it took place at a time when monetary policy was tight as measured by the growth of Ml and the high real irterest rates or by the expansion of the monetary base, which contracted in January and February (see figure 2 and table i). Once again, the authorities resorted to a price freeze in order to regain control over the inflationary process. This policy response indicates that the authorities were under the impression that the underlying "fundamentals" were in place and that inflation was accelerating as a result of "Inertial" forces. This interpretation could have been reinforced by the fact that inflation was increasing at a time when monetary pollcy was tight.

Three remarks are useful for the interpretation of these events. First, although monetary policy remained tight during most of the Spring plan, including January and February, It had been expansionary in the last two months of_1986. Second, there was an important fiscal imbalance in the last quarter of 1986 which remained in place in the first quarter of 1987 and was likely to stay there for the rest of the year. The existence of a large fiscal deficit made the stabilization policy less credible and, more importantly, It threatened the sustainability of tight money, which 
eventually had to give in. Third, firms may have overreacted in their price adjustments in January and February (once the price controls were partly relaxed) and increased their prices in excess of what was warranted by the "Eundamentals" in order to hold a cushion for the eventual imposition of a new round of price controls (to which the authorities had already shown some addiction).

Inflation was becoming a major liability for the govermment, and the problem was particularly acute because 1987 was an election year. Something had to be done in order to deal with inflation before the situation got completely out of control. The government response was a new round of direct controls through the introduction of a price-exchange rate freeze which was supplemented by a step adjustment in wages and public sector prices (to compensate for past inflation) followed by a freeze. Once again, no effort was made to provide a long term solution to the underlying fiscal problem. The February program, as most of the others, had some transitory gains on the inflation front, with inflation falling substantially in April and May. 23 Direct controls can be effective in the short run. Howevar, this time the success was much shorter because the imbalance in the underlying fundamental variables was complicated by political problems that eventually led to mismanagement of cominal varlables.

The main political development was the appointment of Carlos Alderete, a union leader. 98 minister of labor in April. This led very quickly to a change in policy, perticularly regarding wages, which was announced on May 9. The new measures were the result of an agreement (the Acuerdo del 9 de mayo)

23 There was some reduction in inflation in March as well, but this is not fully reflected in the official statistics due to methodological problems. 
between the economic team, led by Sourrouille and Alderete and included Increases in wages and public sector prices, while prices in the private sector would continue to be subjected to government controls, but under a more flexible policy.

d) The Two Latest Inflation-Stabilization Cycles

From that time on, the overall economic situation underwent a steady deterioration. Loose monetary management, and large budget deficits led to a new acceleration in inflation, reaching 13 percent in August and 19.5 percent In October, when the government launched a new minl stabilization program. Once again, the acceleration in inflation appears to have been caused by a mixture of fiscal imbalances, and anticipations of controls. The increase in inflation prompted the imposition of price controls, making the expectations of their reimposition self-fulfiling.

The October package was different from the previous ones because this time the authorities announced measures to provide some longer term relief to the flscal imbalance and to start a structural adjustment process in the economy. Most of the reduction of the budget deficit was going to take place through increases in taxes, while there were basically no attempts to reduce government expenditure of the central government. On the other hand, there was an announcement of a firm commitment to privatize some public state enterprises and to start a process of trade liberalization.

The outcome of this program, as the reader might expect, was a transitory reduction in inflation, whlle the controls were in effect. followed by an increase in inflation at a later stage, once the controls were relaxed (in January 1988). From that time on, inflation sontinuously accelerated reaching 28 percent in August 1988. 
The response to the latest inflationary outburst was the new Spring Plan, based on guidelines for increases in nominal varlables, and reductions in the quasi-fiscal deficit. The exchange rate and public sector prices recovered their role as nominal anchors, and their increases have been preannounced for the next few months. Private sector wages, however, have been allowed to be freely determined through negotiation between firms and workers. Tight money and high interest rates are an integral part of the plan.

The program has achleved the same, or even more, degree of short run success than previous stabilization efforts. Inflation fell substantially. the exchange rate has been stabilized while interest rates are high in real terms. Despite the greater discipline displayed on the fiscal side and the tough monetary policy. 1ts long run success is still doubtful. Few structural measures have been taken to deal with the budget deficit, most of the fiscal adjustment is based on arrears and postponement of public Investment, while it is difficult to believe that the current real interest rates (exceeding 5 percent per month) can 8 tay for a long period.

IV. Evaluation of the Recent Experience

The macroeconomic developments of the last three years show quite clearly that the Austral plan did not succeed in bringing down inflation on a sustained bas1s. The program, however, left useful lessons regarding the design of heterodox stablization programs, the difficulties in sustaining this type of effort, and the consequences of failure.

\section{a) Early Developments}


A balanced evaluation of this plan should distinguish between the original strategy for stopping inflation, with particular attention to the measures of June 1985, and the subsequent efforts for maintaining price stabllity. The initial package was by and large well designed and consistent, and provided a sound first step towards reducing inflation. It was not enough, however, to maintain price stabllity for a prolonged period. Further measures had to be taken in order to consolidate the stabilization effort, particularly on the fiscal side, prior to the removal of controls. In addition, the success of the strategy required the authorities to be ready to accept some costs, in terms of increases in unemployment or at least postponement of growth, if it the overall macroeconomic conditions made it necessary.

Fundamental reforms of the fiscal side were necessary since the initial adjustment was precarious and of a transitory nature. Nevertheless, no drastic measures wore introduced to ensure permanent reductions in government expenditure wile no efforts were undertaken to ensure that the increase in revenues --largely resulting from transitory measures-- would be sustained. A fiscal reform and a restructuring of public sector enterprises were imperative, but not undertaken. 24

24 A flscal reform was finally introduced in October 1987, including the Introduction of new taxes and changes in the rates of existing ones. This reform, however, was too little too late, while it introduced additional distortions in the economy (1.e. It is likely to reduce financial intermediation and restrict imports). In addition, the authoritles seem to be finally moving in the direction of reducing the size of the public sector, and 18 involved in negotiations to privatize various public sector enterprises. These are welcomed developments and hopefully will be successfully completed, however, as of November 1988, very little has been accomplished. 
A more difficult issue, from a policy perspective, was how to respond to the early recovery of the economy that started in the fourth quarter of 1985. Although one of the objectives of the heterodox package is to reduce the costs of bringing down inflation, the strategy does not call for a rapid expansion in output in the early stages. There is no consensus regarding the main reason behind the early expansion in economic activity. It might have been caused by a change in inccme distribution (the reduction in the inflation tax redistributed income in favor to wage earners), by a relaxation in monetary and flscal policles, or by an improvement in efficlency as a result of the sharp reduction in inflation. Nevertheless, it is questionable whether this was not a welcomed development at the early stages of a stabilization program in an economy with widespread price controls.

A demand-led economic expansion was a clear threat to price stability. The policy choices were difficult, since most likely they required the acceptance of some of the costs that the heterodox package was intended to avoid. Nevertheless, it is my view that further fiscal tightening and restrictive monetary policy were necessary at the time in order to compensate for the increase in private sector demand. It was advisable to pursue a policy of excess supplies at least unt 11 most prices were liberalize.

The lack of policy response to the developments in these two areas were important because they provided evidence on the way in which the authorities were going to address potential problems. In addition, with the benefit of hindsight, it indicates that they had not thought thoroughly the steps that would be necessary to liberalize prices without bringing back inflation.

b) Removal of Controls

The strategy for price liberalization 18 a crucial aspect of a 
heterodox program. Price stability can only be fully credible in an environment of freely determined prices. The overall scheme for liberalizing prices is critical and needs as much thought as the design of the initial phase of the program. Particular attention should be ifiven to the timing. conditions and mechanics of the removal of controls.

It was argued in the previous section that price controls were a cruclal element for stopping inflation. Paradoxically, the main advantage of controls is also their main 1rawback. The quick reduction in inflation that can be achieved through controls can make the authorities overconfident and lead them to underestimate the seriousness of any existing underlying imbalances. In particular, it might lead them to think that no further measures are necessary to sustain the early gains against inflation. In addition, since controls proved to be an effective way to bring about price stability, the authorities might become reluctant to eliminate them. The process might be further complicated if the freeze of nominal anchors is extended beyond a reasonable time and distortions in key relative prices become apparent. 25 This is indeed a major weakness of the heterodox approach.

The removal of controls, however, should be a priority for the program. Controls should be removed gradually and under a situation of generalized excess supplies. Tight fiscal and monetary policles should remain in place during the period of price "flexibilization". In Argentina "flexibilization" was initlated at a time when the economy was rapidly expanding and the

25 This is the typical problem observed in the so called populist stabilization programs (e.g. the 1973-5 Peronist program, and the recent Peruvian one) where in addition price controls are used as a substitute for the correction in fundamentals. 
current account deficits were increasing. The public accounts had also been deterforating. Price flexibllization was thus not undertaken under the best c1rcumstances.

A more serious problem was that with the removal of controls the economy wes left with no nominal anchors. A nominal anchor was particularly Important since in the absence of controls prices and wages would be determined by market forces. Since the exchange rate, public sector prices and the money supply were basically adjusted to accommodate inflation, there ras no nominal varlable to anchor the rate of inflation. Given the necessary adjustments in public sector prices and the exchange rate, money should have played a more active role in this period, while the authorities should have pursued a policy, from that time on, of untying devaluations to past Inflation.

An alternative sequencing might have provided more atability to the price level. In the Austral plan the removal of controls coincided with the a flexibilization in the management of the main anchors of the 8jotem. A gradual decontrol of private prices followed by a sequenced adjustment in wages, public sector prices and the exchange rate would have had, in my view, a better chance of success. c) The Importance of Foreign Debt and External Developments

It is difficult to 28888 she extent to which the external situation complicated the stabilization effort. An extreme view is that of Canavese and DI Tella (1988) who conslder that "repayment of the debt was the single most important reason for the relative fallure of the plan". (p.166) Although service of the external debt introduces an additional burden to the flscal adjustment (interest payments are approximately 58 of GDP), the 
country was able to get additional funds to cover more than half of these payments. Actual net external transfers during 1985-87 were roughly 27 percent of GDP per year. Thus, the Eiscal burden of interest payments, while important, does sot seem to have been the critical problem for the program.

The debt problem, however, created other types of difficulties for the stabilization program. First, it greatly complicated the reliance on the exchange rate as the main nominal anchor of the system. In the absence of access to foreign borrowing, the exchange rate would have to adjust if there were pressures on the external sector. Second, and probably more important, It increased the uncertainty about the medium term sustainability of the program. Even if funds had been provided In the past to service the debt, there were questions as to whether those funds would be ready to come in the future. The debt issue also created a problem regarding management of public Elnances, since the government had to raise taxes in the future to continue servicing external debt.

The external situation has been complicated by a ignificant deterforation in the terms of trade during the last two gears. While it would be unfalr to attribute the fallure of the program to the service of the forelgn debt, Its burden and the resulting increase in uncertainty certainly complicated the macro-management during this period. One thing is clear. external developments were not favorable for the success of the program. d) Les8ons and Pollcy 188408

The Austral plan, desplte its fallure, has left useful lessons for the future design and implementation of stabilization programs in general and heterodox programs in particular. First, it has shown that stopping inflation on a sustainsble basis 18 essentially a long term effort which 
requires persistency and discipline. The duration and scope of this effort will be inversely related to the length of the inflationary process, the level of the rate of inflation prior to the program and the number of previous fallures. Incone policles can be very useful to bring down inflation quickly, but this short run success needs to be accompanied by a sustained fiscal and monetary effort to ensure the maintenance of the price stability.

Second, the Argentine experience is particularly illuminating regarding the advantages and disadvantages of price controls. They were very effective initially to break the inertial forces as the economy moved from high to low inflation. It is unlikely that the rapid reduction in inflation at the beginning of the program could have been achleved in the absence of price controls. This, however, is an instrument that serves a very specific purpose, control of the inertial aspects of the inflation process; to be effective, it must be used cautiously, and on transitory basis. Controls should be gradually removed 88 soon as the authoritles percelve that the underlying inertial forces have been subdued.

One problem with price controls is that they could send a "wrong" 8ignal about the success of a program. In most cases price controls are an effective tool to bring down inflation, at least tempu.arily. Indeed, In Argentine inflation came down initially every time price controls were introduced. Onfortunately, Inflation went up every time they were removed. 26 Thus, In general it 18 very difficult to infer the underlying inflation rate

26 Interestingly enough, there were no widespread shortages in any of these cases. Thus, the acceleration in inflation following the removal of controls cannot be eas1ly Iinked to the existence of "repressed" Inflation due to excess demand pressures. 
on the basis of the rate of inflation observed during a period when controls are in effect. An additional problem is that their short run effectiveness can lead the authorities to use them each time that inflation starts to accelerate. This again was observed in the recent Argentine experience, where price controls became the primary instrument to control inflation.

The repeated use of controls quickly becomes a tool that works against any stabilization effort. The inflation cycles shown in figure 2, are 11lustrative of this problem. The inflation outbursts that occurred prior to the actual imposition of controls can probably be best explain by anticipations by the private sector. If firms expect a price freeze, they would attempt to enter the freeze with a high absolute price. Although this price might be above the market clearing level at the time of the freeze, It will be on average right while the freeze remains in effect. This 18 point of view appears to be supported by the behavior of prices during the period under consideration. In Argentina, price controls were enforced at the wholesale level. As 18 apparent from table 1, Increases in wholesale prices were larger prlor to each of the major freezes (particularly in June 85, October 87 and June-August 88 ), and smaller after the freeze. These larger increases prior to the freeze provided enough cushion to maintaln a $11 d$ on price increases during the period of controls and at least partly explains the lack of shortages during these periods.

The Inflation-stabilization cycle that has been observed since June 1985, was to some extent related to the stab111zation strategy followed by the government. The fact that the government revealed its decision of using price controls once, created expectations that they could be used again in the future. In this environment, small increases in inflation could very 
quickly spark an acceleration process in anticipation of the reimposition of controls. The government eventually responds by imposing new controls making the expectations self fulfilling.

Despite their advantage for reducing inflation price controls can be costly on two grounds. First, they could be difficult to remove and hence lead to distortions in relative prices. Second, and probably more important, a fall in this program could increase instability in the inflation process. The experience of the last few years have made quite clear that tight money cannot be sustained in the presence of a large fiscal imbalance. This of course is well known from Sargent-Wallace (1981), and is very clear from the recent Argentine experience. Figure 2 shows inflation and interest rates on deposits since the beginning of the Austral plan. Tight money was used to control infiation twice; from August 86 to February 87 , and from October 87 till January 88. In neither of these sases was the policy effective to control inflation on a medium term basis. As a matter of fact, in both cases inflation accelerated during the period in which tight money was in effect.

The Austral plan has added a new chapter to the unsuccessful efforts to stopping inflation. Despite the sophistication of the original design of the plan and the battery of follow up programs, Inflation is st111 alive and price stability still appears as a distant proposition. It seems that few lessons were learned from previous fallures, as similar mistakes were repested. The most important lesson from the Austral Plan is that sophistication 18 not a substitute for addressing fundamentals imbalances. There is no substitute for persistence and continuity in a stabilization effort. The unfortunate side is that each new fallure makes the path to price stability more remote and more difficult. 
REFERENCES

Adams, Charles and Dan1el Gross (1986). "The Consequences of Real Exchange Rate Rules for Inflation: Some Illustrative Examples," IMF Staff Paper8, Vol.33 No. 3, PP. 439-76.

Blejer, Mario and Nissan Liviatan (1987). "Fighting Hyperinflation: Stabilization Strategies in Argentina and I8rael 1985-86, "IMF Staff Papers. Vol 34, No. 3, Pp. 403-38.

Broda, Miguel Angel (1987). "La Polltica Monetarla y Plocal desde el Plan Austral; Porque se Perdlo la Oportunidad?" Anales de la Asociacion Argentina de Economia Politica, Vol 1, pp. 295-320.

Canavese, Alfredo and Guido DI Tella (1988). "Inflation Stabllization or Hyperinflation Avoldance: The Case of the Austral Plan In Argentina, 198587." In Inflation Stabllization: The Experlence of Israel, Argentina Braz11, Bolivia and Mexico, M. Bruno, G. DI Tella, R. Dornbusch and Stanley Flocher. Ed1tor8. Cambridge, Massachusetts: The MIT Pres8, pp. 153-90.

De Pablo, Juan Carlos (1987). "Transicion Hacia las Urnas, Confusion Inicial y Plan Austral; Argentina, 1982-87." mimeo.

De Pablo, Juan Carlos and Adolfo Martinez (1988). Macroeconomic Policles, Crisis and Growth in the Long Run - Argentina Country Study, mimeo, The World Bank.

Dormbusch, Rudiger (1986). "Money Interest Rates and Stab1l1zation," Review of Economic Conditions in Italy. Vol. 3, pp.439-53.

Frenkel, Roberto and Jose Maria Fanell1 (1987). "El Plan Australs Un Ano 9 Medio Despues," El Trimestre Economico, Vol 54, Special Number, Pp. 55-118.

Heyman, Daniel (1987). "The Austral Plan," Amertcan Economic Review. Vol. 77, No. 2, Pp. 284-87.

Indicadores de Coyuntura, Fundacion de Investigaciones Economicas Latinoamericanas, Buenos Alres, various issues.

Riguel._Miguel A. and Nissan Liviatan (1988). "Inflationary Rigidities and Orthodox Stabilization Programs: Lessons from Latin America," The World Bank Economic Rev1ew, Vol 2 /3, pp.273-98.

Machlnea, Jose Luis and Jose M. Panell1 (1987). "Stopping Hyperinflation: The Case of the Austrai Plan in Argentina, 1985-87, "In Inflation Stabilization, pp.111-52.

Paz08, Pellpe (1972). Chronlc Inflation in Latin America, Praeger. 
Rodriguez, Carlos (1988). "Corments on the Austral Plan," In Inflation Stabilization, pp.202-09.

Sachs, Jeffrey (1986). "The Bolivian Hyperinflation and Stabilization," NBER Working Paper, No.2073.

Sargent, Thomas and Nell Wallace, (1981). "Some Unpleasant Monetarist Ar1thment1c," Federal Reserve Bank of Minneapolis Quarterly Review, PP. 1-17. 
Table 1

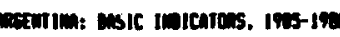

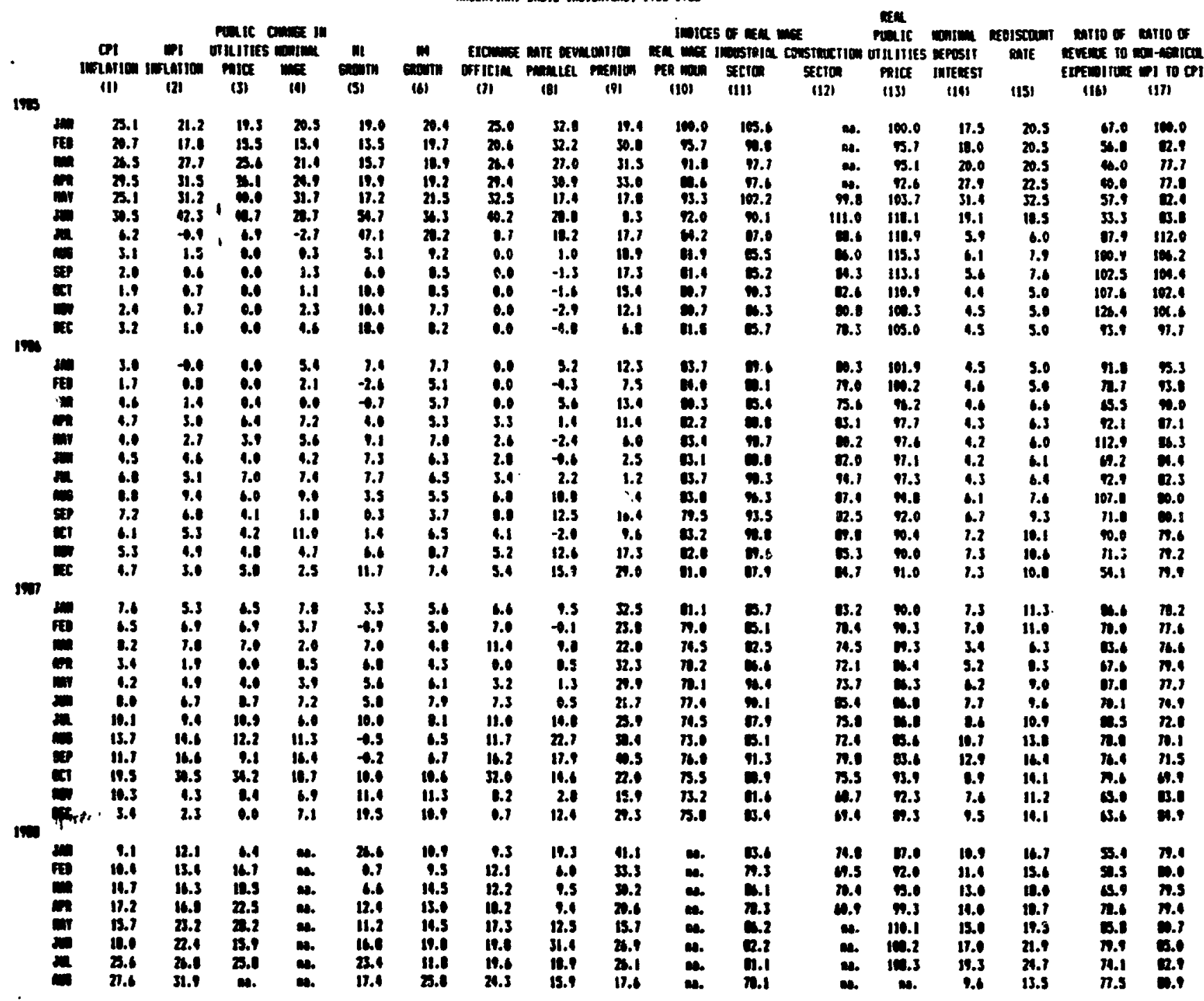

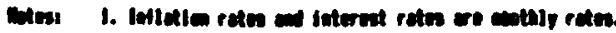

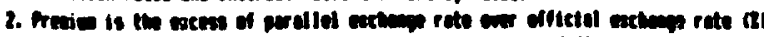

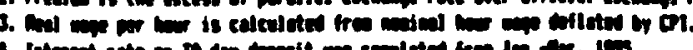

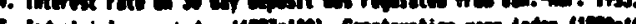

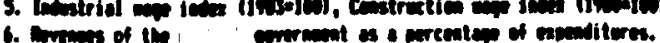


EXPENDITURES, REVENUES, TOTAL FISCAL DEFICIT, AND SEIGNDRAEE (CASH BASIS, AS \% QF GDP)

NON FINANICAL PUBLIC
EXPENDI TURES REVENUES
$\begin{array}{ll}\text { (1) } & \text { (2) }\end{array}$

SECTOR
DEFICIT

(3)
29.2

31.5

1985

$\begin{array}{rr} & 31.0 \\ \text { II } & 29.5 \\ \text { III } & 28.9 \\ \text { IV } & 30.4\end{array}$

1986

$\begin{aligned} & 29.6 \\ \text { I } & 29.2 \\ \text { II } & 28.6 \\ \text { II } & 27.2 \\ & 29.4\end{aligned}$

1987

$\begin{array}{rr} & 30.7 \\ I & 29.0 \\ I I & 32.0 \\ \text { II } & 29.4\end{array}$

IV
103

6.3

B. 6

23.1

22.9

22.9

27.5

22.0

22.0

28.6

31.8

3.5

7.5

6.9

1.8

1.3

25.9

26.9

27.7

26.4

23.7

2.7

2.3

0.9

0.8

5. 7

24.4

24.2

25.5

25.0

23.6

6.3

3. 9

6.5

4.4

8. 5
8. 3

9.5

CENTRAL

BANK

DEF ICIT

(4)

2.7

5.6

6.0

3. 1

2.3

2.4

4.4

5.0

1.2

0.9
1.9

1.7

1. 3

2.2

2.1

0.9

1. 8

1.7

1.4

$-1.2$
TOTAL
DEFICIT

(S)

11.0
15.1
16.3
7.4
10.9

5.9

11.9

11.9

3.0

2. 2

4.6

\$. 0

2.2

3.0

7. $\mathrm{B}$

7.2

5.6

B. 2

5. 8

7.3
ALTERNATIVE BUDGET

DEFICIT SEIGNORAG

(G)

(7)

11.4

12.0

23.7

5. 8

3.9

6.0

11.5

10. 0

7.4

5.4

4. 3

3.6

6. 8

6.7

2.3

5.4

3.0

5.3

7.7

6.6

7.5

7.8

B. 7$$
2.0
$$

4.4

2.3

15.7

$\begin{array}{rr}12.1 & \\ 9.2 & 9.8 \\ 20.2 & 9.1 \\ 8.8 & 8.3 \\ 10.0 & 7.9\end{array}$

(1) - Includes National and Provincial Governments, Social Security System and current account deficita of public encerprises.

(2) - Excludes current revenue of public enterprises.

(3) - Secretary of Treasury estimation

(4) - Central Bank estimation. This figure usually differs from the one abtained by the Treasury (3). While the Treasury figure is obtained with date "above the Iine", the Central Bank figure is obtained with data "oerow the line".

$(5)-(3)+(4)$

(6) - Calculated on the basis of change in public sector debt, (sources Fudacion Mediterranea).

(7) - Seignorage $=M(t)-M(t-1) /$ GNP $(t)$ 
GuP CONSUAPTIO NATIONAL ACCOONTS (MILLION AOSTRALS 1970 PRICLS)
BALAic: of PAYITITS

CORrant TRADT FIMANCIAL chaner IN TERMS OF

ACCOUNT BALANC BTRVICES RESERVES TRADE

(HILLION OS 0.8. DOLGARS)

$$
\begin{array}{rr}
1984.1 & 10212.8 \\
1884.2 & 10515.5 \\
1884.3 & 10392.8 \\
1984.4 & 11138.0 \\
1885.1 & 10102.6 \\
1986.2 & 10031.1 \\
1885.3 & 9481.4 \\
1886.4 & 10793.5 \\
1886.1 & 10182.7 \\
1888.2 & 10648.3 \\
1986.3 & 10584.6 \\
1986.4 & 11198.1 \\
1887.1 & 10424.0 \\
1987.2 & 10888.7
\end{array}
$$

8850.8

928.2

1391.8

1226.0

1681.8

1086.1

1121.6

843.2

1151.2

1213.2

1282.7

1186.9

1360.0

1062.6

1588.9

1448.2

$\begin{array}{rr}1858.6 & -197.0 \\ 2363.7 & -137.5 \\ 2388.4 & -748.6 \\ 2289.5 & -1308.0 \\ 1893.5 & -779.8 \\ 2059.3 & 186.8 \\ 1933.0 & 109.9 \\ 2194.7 & -468.8 \\ 1892.1 & -803.0 \\ 2274.6 & -456.0 \\ 2448.0 & -608.0 \\ 2408.0 & -1092.0 \\ 2046.1 & -1027.0 \\ 2386.7 & -809.0 \\ 2373.8 & -1116.0\end{array}$

1284.0

1350.0

755.0

124.0

826.0

1643.0

1331.0

782.0

582.0

814.0

541.0

179.0

241.0

362.0

$-17.0$
$-1351.4$

$-1448.2$

$-1471.6$

$-1440.8$

$-1.441 .1$

$-1428.5$

$-1221.6$

$-1214.0$

$-1147.0$

$-1186.0$

$-934.0$

$-1138.0$

$-1042.0$

$-1157.0$

$-1044.0$
672.6

297.8

$-488.3$

$-217.3$

$-288.3$

821.6

1436.6

523.2

$-435.0$

1441.3

$-380.0$

$-1038.0$

$-461.0$

$-1368.0$

N/A
104.

91.

91.

112.

121.

107.

100.

96.

102.

85.

86.

82.

88.

83.

85.

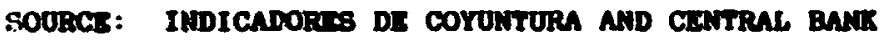


Figure 1

ARGENTINA: FISCAL DEFICIT AND INFLATION

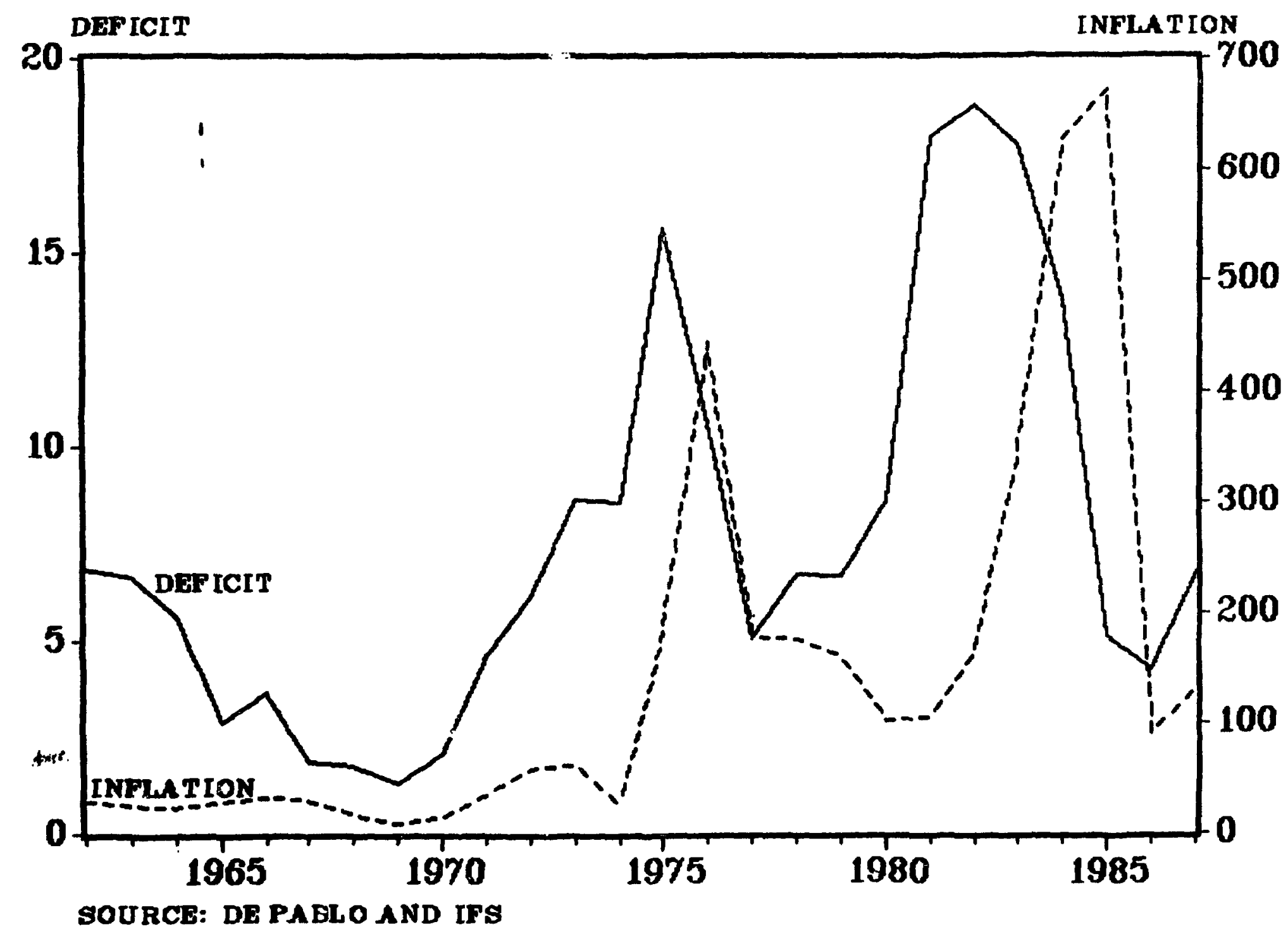


Figure 2

ARGENTINA: WPI INFLATION AND DEPOSIT RATE

INFLATION, INTE REST RATE (\% IN MONTHLY TE EMS)

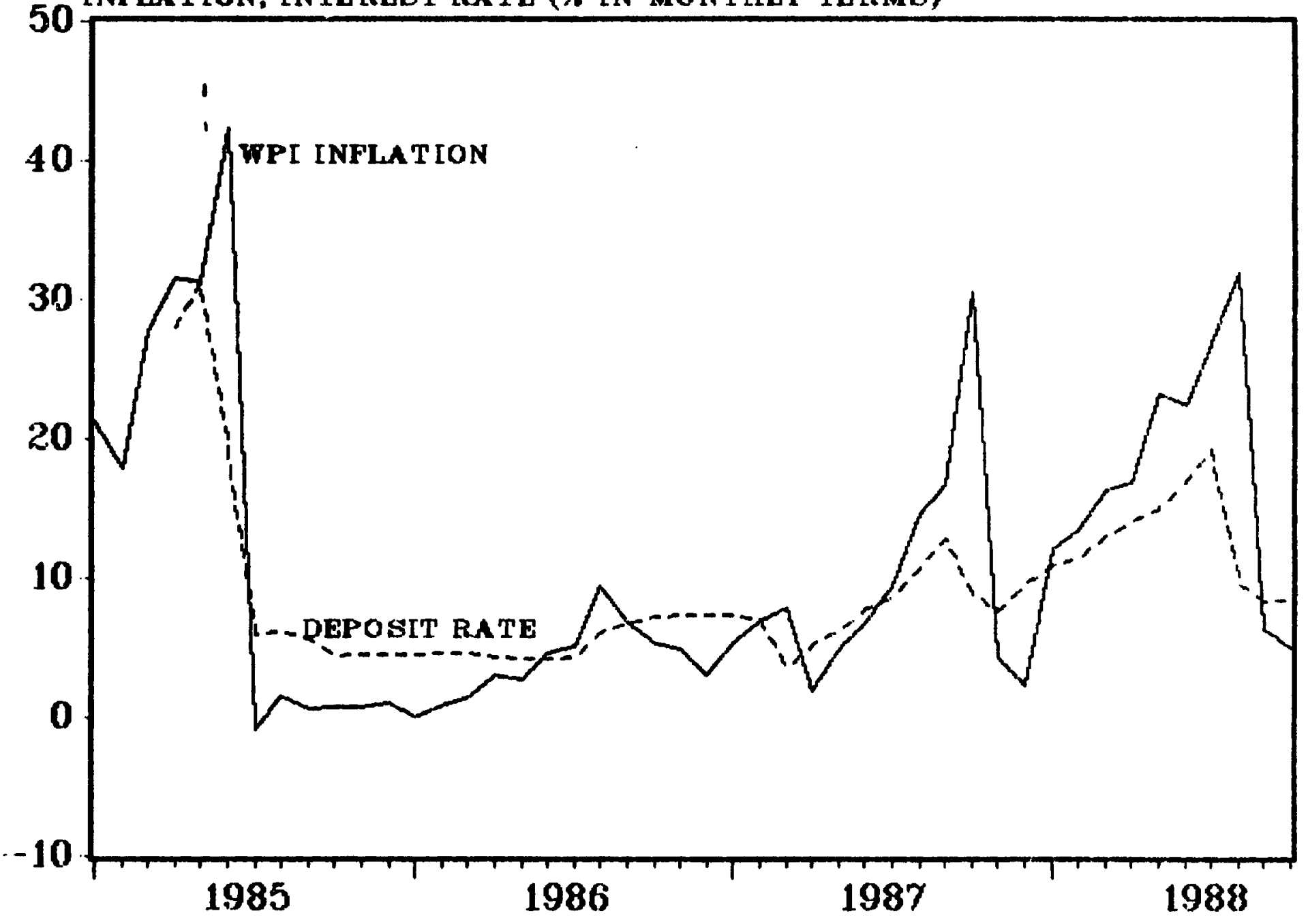




\section{Titie}

WPS141 Payroll Taxes for Financing Training

in Developing Countries

WPS142 Vocational Secondary Schooling in Israel: A Study of Labor Market Outcomes

WPS143 Decentralizstion in Education: An Economic Perspective

WPS144 Product Differentiation and the Treatment of Foreign Trade in CGE Models of Small Economies

WPS145 Revenue Raising Taxes: General Equilibrium Evaluation of Alternative Taxation in U.S. Petroleum Industries

WPS146 Exchange Rate-Based Disinflation, Wage Rigidity, and Capital Inflows:

Tradeoffs for Chile 1977-81

WPS147 The Private Sector's Response to Financial Liberalization in Turkey: 1980-82 World Coffee Market

WPS149 Reflections on Perestroyka and the Foreign Economic Ties of the USSR

WPS150 Improving the Currency Composition of External Debt: Applications in Indonesia and Turkey

Julie Stanton
Izak Atiyas

Takamasa Ak. yama

Panayotis N. Varangis

February 1989

Date

Contact

Adrian Ziderman

January 1989

C. Cristobal 33640

January 1989

C. Cristobal 33640

Donald R. Winkler

Jaime de Meto

Sherman Robinson

February $1989 \quad$ K. Cabana

.61539

Jaime de Melo

February 1989

K. Cabana

61539

Timothy Condon

February 1989

K. Cabana

61539

Jaime de Melo

January 1989

W. Pitayatonakarn 60353

Bela Balassa

January 1989

N. Campbell

33769

Ken Kroner

Stijn Claessens
January 1989

L. Chavarria 33730 


\section{$1+10$}

WPS151 U.S. Trade Pollcy Towards

Developing Countries

WPS152 Subsidies and Countervailing Measures: Economic Considerations

Bela Balassa

January 1989

I shac Diwan

Stijn Claessens

WPS154 Forecasting, Uncertainty and Public Project Appraisal

Jock R, Anderson

I an Timaeus

Wendy Graham

WPS156 Credit Cooperatives in Israeli

Agriculture

Yoav Kislev

Zvi Lerman

Pinhas Zusman

WPS157 A Policy Model for Tunisla with

Real and Financial Flows

WPS158 Labor Redundancy in the Transport Sector

WPS159 Current International Gas Trades and Prices

WPS160 Evaluating the Performance of Public Enterprises in Pakistan

WPS161 Commodity-Indexed Debt in International Lending

Timothy Besley Andrew Powell

Miguel A. Kiguel

Date

Contact

January 1989

N. Campbell 33769

N. Campbell 33769

Fobruary 1989

A. Kitson-Walters 33712

March 1989

C. Spooner 37570

January 1989

A. Bhalla

Marc Leduc

Setareh Razmara

Alice Galenson

February 1989

W. Wright

33744

Kay McKeough

March 1989

M. Fernandez 33637

Mary M. Shirley

March 1989

R. Malcolm 61708

March 1989

J. Raulin 33715

WPS162 Inflation in Argentina: Stop and Go Since the Austral Plan
R. Luz 61761 